\title{
The hypocrisy - changing the vices into virtues
}

\author{
Iosif Tamaș
}

Iosif Tamaş - PhD, researcher, Institute of Interdisciplinary Research, Departament of Social Sciences and Humanities, Alexandru Ioan Cuza University of Iași

\begin{abstract}
This article focuses on identifying and presenting the roots and consequences of hypocrisy within the hidden pathological features of the human being. Hypocrisy belongs to the hypocrite, that is, to the individual in his ontic integrity as an immortal body, spirit, and soul. In this respect this scientific discourse has its place within the religious space as well, at the spiritual level of the perfect process of creation, where the new spiritual individual is always active; At the empirical, scientific and material level of the human activity there is only the ideological individual, proficient or not, just like in the unfortunate case of the priest sacerdos in aeternum who became professor after he jumped the fence of the house and he got into the yard of the University, with the passport in his pocket of course. We will approach the subject strictly through the paradigm of the theological-philosophical discourse, framed by the constitutive horizon of moral philosophy (philosophical ethics), which is defined as the second strand of bioethics as a modern science, according to the traditional medical ethics (1). Within this paper we will look at the following points: the formalism of religious hypocrisy; the blindness of the hypocrite as a pathological manifestation and finally about the availability as a permanent risk of hypocrisy.
\end{abstract}

\section{KEYWORDS:}

Vice, virtue, disease, [our] faith, pride.

\section{INTRODUCTION}

Being a mistake against reason, truth, a violation of a commandment, sin was called by St. Augustine "a word, deed, or desire contrary to eternal law," to the point of selflove and contempt for God (2). This is how the wise prophets once said: „Domnul zice:
„Pentru că poporul acesta se apropie de mine cu gura şi mă preamăreşte cu buzele, dar inima lui este departe de mine, iar teama de mine este o poruncă învăţată de la oameni, de aceea, voi face din nou fapte minunate pentru acest popor, va pieri înţelepciunea celor inţelepţi şi priceperea celor pricepuţi va 
122/Bulletin of Integrative Psychiatry ONew Series O September 2021 O Year XXVII ONo. 3(90)

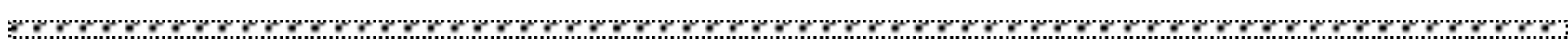

dispărea. Vai de cei care-şi ascund planul departe de Domnul, iar faptele lor sunt în intuneric şi zic: "Cine ne vede şi cine ne cunoaşte?»!" (Is 29, 13-15), [“The Lord says: "For this people draweth nigh unto me with their mouth, and honoureth me with their lips; but their heart is far from me, and their fear is a commandment learned from men, therefore I will do wonders for this people again, and the wisdom of the wise shall perish, and the understanding of the prudent shall depart. Woe unto them that seek deep to hide their counsel from the Lord, and their works are in the dark, and I say, 'Who seeth us, and who knoweth us?"'(Is 29, 13-15)], (3). Thus, it is Jesus of Nazareth who will identify and reveal the roots and pathological consequences of hypocrisy. According to his principle that the healthy do not need a doctor, Jesus turned to those who represented the verticality of the spiritual life of his time, to those who at that time took the "intelligence" (4) of the time, in a word to the teachers of the law, the scholars and hypocrites. The central idea emphasized by Jesus was that the facts did not express the intention, the causality of the actions determining the results: the blind man unable to see the light rises as a guide. Being aware that they were blind, they deceived themselves out of a perverse desire to deceive others. Here is the edifying passage: „Vai vouă, cărturarilor şi fariseilor ipocriţi! Voi daţi zeciuială din mentă, din mărar şi din chimion, dar lăsaţi la o parte ce este mai greu din Lege: judecata, indurarea, credinţa.
Acestea trebuia să le faceţi, iar pe acelea să nu le neglijaţi! Călăuze oarbe! Voi strecuraţi ţânţarul, dar înghiţiţi cămila. Vai vouă, cărturarilor şi fariseilor ipocriţi! Voi curăţaţi exteriorul paharului şi al farfuriei, dar în interior sunt pline de jaf şi necumpătare. Fariseu orb! Curăţă mai întâi interiorul paharului ca să devină curat şi exteriorul lui." ["Woe unto you, scribes and Pharisees, hypocrites! You tithe mint, dill, and cumin, but set aside the heaviest part of the law: judgment, mercy, faith. You had to do these, and don't neglect those! Blind guides! You sneak in the mosquito, but swallow the camel. Woe unto you, scribes and Pharisees, hypocrites! You clean the outside of the glass and the plate, but inside they are full of robbery and intemperance. Blind Pharisee! First clean the inside of the glass to make it clean.”] (Mt. 23, 23-26). This is the starting point. Where did I end up today? According to our scientific opinion, it is more difficult today: our "intelligence" translates to us what Jesus meant!

\section{THE FORMALISM OF RELIGIOUS HYPOCRISY}

Religious hypocrisy is not just a lie; it is a case of psychiatric clinical study, because here we find ourselves in the field of the pyramid apex syndrome. The religious hypocrite deceives his neighbor to gain his esteem, with gestures, with folklore, with lyrical moments, with symposia, meetings, synods and councils, with congresses, be they 
Bulletin of Integrative Psychiatry $\bigcirc$ New Series OSeptember $2021 \bigcirc$ Year XXVII ONo. 3(90)/123

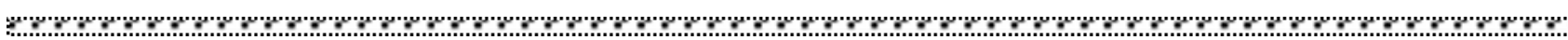

Eucharistic, whose intention is not at all simple, all bearing the confessional imprint. Only then will the non-Christian be able to say about Christians: this is how much they love each other! "Promoting the REBUILDING of UNITY among all Christians is one of the main goals of the holy Second Vatican Ecumenical Council" (5). The hypocrite, stirrer or propagandist, seems to act for God, when in fact, he acts only for himself or for the institution he represents. The formula of the cult of personality was abandoned and instead other formulas emerged, such as the citizen of honor, emeritus. The most recommended practices of Christian piety, prayer, fasting and almsgiving, are thus perverted by the concern "to be noticed", and the media abound with examples in this regard. ,Aşadar, când dai de pomană, nu trâmbiţa înaintea ta aşa cum fac ipocriţii în sinagogi şi în pieţe, ca să fie lăudaţi de oameni. Adevăr vă spun: şi-au primit răsplata. Iar când vă rugaţi, nu faceţi ca ipocriţii, pentru că lor le place să se roage stând în picioare în sinagogi şi la colţurile străzilor ca să se arate oamenilor! Adevăr vă spun: şi-au primit răsplata. Când postiţi, nu fiţi trişti ca ipocriţii, căci ei îşi schimonosesc fețele ca să arate oamenilor că postesc! Adevăr vă spun: şi-au primit răsplata. Toate faptele lor le fac pentru a fi văzuţi de oameni: îşi lărgesc filacterele şi îşi lungesc ciucurii." ["Therefore when thou doest thine alms, do not sound a trumpet before thee, as the hypocrites do in the synagogues and in the markets, that they may be praised of men. Truth be told: they have received their reward. And when thou prayest, thou shalt not be as the hypocrites are: for they love to pray standing in the synagogues and in the corners of the streets, that they may be seen of men. Truth be told: they have received their reward. When you fast, do not be as sad as hypocrites, for they twist their faces to show people that they are fasting! Truth be told: they have received their reward. They do all their deeds to be seen by men: they enlarge their phylacteries and lengthen their tassels."] (Mt $6,2.5 .16 ; 23.5)$. To put a barrier between the heart and the lips this education teaches man to hide evil intentions under a honeyed air, hence the nicknames Machiavellian, Jesuit. Such an episode occurred when a trap was laid under the cover of a legal question for Jesus: „Dar Isus, cunoscând răutatea lor, le-a zis: „Ipocriţilor, de ce mă ispitiţi? Arătaţi-mi moneda tributului!”. Iar ei i-au adus un dinár. El le-a zis: „Ale cui sunt imaginea aceasta şi inscriptia?”. I-au zis: „Ale Cezárului”. Atunci le-a zis: „Daţi-i, aşadar, Cezárului ceea ce este al Cezárului şi lui Dumnezeu ceea ce este al lui Dumnezeu!”. Când au auzit, au rămas uimiţi şi, lăsându-l, au plecat." ["But Jesus, knowing their wickedness, said to them," Why are you tempting the hypocrites? Show me the tribute coin! "And they brought him a penny. He said to them, "Whose is this image and inscription?" They said to him, "Caesar's." Then said he unto them, Render therefore 
unto Caesar the things which are Caesar's; and unto God the things that are God's. When they heard this, they were astonished, and went away from him.] (Mt 22, 18-23). Nothing new under the sun would say the Ecclesiastes [Book of Qohelét], we have heard the story: „Dar ei au zis: „Veniţi să facem planuri impotriva lui Ieremía! Căci legea nu va pieri din lipsă de preoţi, nici sfatul, din lipsă de inţelepţi şi nici cuvântul, din lipsă de profeţi. Haideţi să-l lovim cu limba şi să nu ţinem cont de niciunul dintre cuvintele sale!"." ["But they said, 'Come and make plans against Jeremiah! For the law shall not perish from the absence of priests, nor counsel from the wisdom of wise men, nor the word from the absence of prophets. Let us smite him with the tongue, and let him not regard any of his words."] (Ier 18, 18). Always determined to come out with a clean face and forehead up, he didn't eat garlic not even his mouth smells, the hypocrite knows how to position himself between precepts or to arrange them in an intelligent casuistry, shouting loudly: I have the answer, who has the question!? And so the sapiential dogmatists were the ones who explained to us how logical it is to believe. And so the mosquito could sneak in and swallow the camel, only then could the divine teachings return in the interest of greed and selfrestraint or group, since the lie has ISBN. We refer strictly to the rudeness of the Communist and religious confessional propagandistic ideology, which, wanting to mask the professional incompetence of each specific competence, of many newcomers, covered the personal "availability" with the institutional mask. How to consider the unqualified, proficient? Even then, the party security "invented the $I S B N$ " (6), and then the propaganda of insane hypocrites blessed and sanctified confessional television and radio stations. And the sad conclusion of the Savior who vibrates even today sends us back to the ancient wisdom: „Ipocriţilor! Bine a profeţit despre voi Isaía, când spune: «Acest popor mă cinsteşte cu buzele, însă inima lor este departe de mine. In zadar mă cinstesc propunând îvvăţături care sunt doar porunci ale oamenilor»" ["Hypocrites! Isaía prophesied well of you when she said, "This people honor me with their lips, but their heart is far from me. In vain do I honor myself by proposing teachings that are only the commandments of men.”] (Mt 15,7-9).

\section{THE BLINDNESS OF THE}

\section{HYPOCRITUS AS A PATHOLOGICAL MANIFESTATION}

Formalism can be treated and cured in the end, but hypocrisy with pathological manifestation certainly leads to stoning. Whitewashed graves end up swallowing everything that flies, everything that they crave, all the truth, all justice, to make others accept, to "believe". They consider themselves the pillars of justice: ,A spus această parabolă unora care se credeau în sine drepţi şi-i dispreţuiau pe alţii; Şi 
Bulletin of Integrative Psychiatry $\bigcirc$ New Series OSeptember 2021 Year XXVII ONo. 3(90)/125

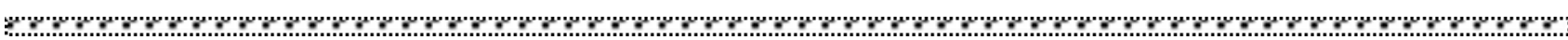

urmărindu-l cu atenţie, au trimis spioni care se prezentau ca fiind drepţi, ca să-l prindă cu vreun cuvânt şi să-l dea pe mâna autorităţii şi a puterii guvernatorului" ["He told this parable to some who believed themselves righteous and despised others; And they followed him closely, and sent spies, pretending to be righteous, to take him by the word, and deliver him into the hand of the governor and to the power of the governor"] (Lk 18:9; 20:20) and become opaque to any call to conversion. Theater actors, Oscar nominees (in Greek hypocrites), hypocritical Christians continue to play their part, especially as they occupy a higher rank and their word is heard. Here is the text: „Atunci Isus s-a adresat mulţimilor şi discipolilor săi, spunând: „Cărturarii şi fariseii s-au aşezat pe catedra lui Moise. Faceţi şi împliniţi tot ce vă spun ei, dar nu faceţi după faptele lor, pentru că ei spun, şi nu fac! " ["Then Jesus addressed his people and disciples, saying," The scribes and the Pharisees sat down on the throne of Moses. Do and do all that they tell you, but do not do according to their deeds, for they say, and do not!'] (Mt 23, 1-3s). Here we meet all those hypocritical propagandists, who from the height of the altars turn into electoral agents, throwing the seed of discord between the parishioners, increasing confusion and duplicity. What does it matter where the money comes from! But more serious is the fact that under the pressure of public opinion, those installed in the chair of Moses send reports about the institutional knowledge of the abominable deeds committed by those of their type. The pain and the will not to repeat the mistakes of the past that is not to put us in the situation of writing and presenting reports. We are the ones who demand guarantees! We are the ones who crush the broken reed, we extinguish the smoking wick! We were lied to! „Durerea este insoțită de o privire de speranță. Pentru ca aceste fenomene nu se mai repete, avem nevoie, pe lângă norme mai eficiente, de o convertire a inimilor. Este nevoie de păstori credibili, vestitori ai Evangheliei, și trebuie să fim cu toții conștienți că acest salt este posibil numai cu ajutorul harului Duhului Sfânt, încrezători fiind în cuvintele lui Isus: Fără mine, nimic nu puteți face" ["The pain is accompanied by a look of hope. Because these phenomena do not happen again, we need, in addition to more efficient rules, a conversion of hearts. We need credible pastors, heralds of the gospel, and we must all be aware that this leap is possible only with the grace of the Holy Spirit, trusting in the words of Jesus: Without me you can do nothing"] (7). Now we woke up from our dogmatic sleep, sorry! Exciting! It's the night of the mind! Brotherly correction is necessary, it is healthy. But here's the dilemma: how can the hypocrite take out the beam that prevents him from seeing, when it doesn't even cross his head, and he has no other concern than how to take out the straw that is in the neighbor's eye? „Sau cum vei spune fratelui tău: «Lasă-mă să 
scot paiul din ochiul tău» şi, iată, bârna este

în ochiul tău? pocritule, scoate mai intâi bârna din ochiul tău şi atunci vei vedea bine să scoţi paiul din ochiul fratelui tău” [“"Or how wilt thou say to thy brother, Let me pull out the mote out of thine eye; and, behold, a beam is in thine own eye? poor thing, take the beam out of your eye first, and then you will see to it that you take the straw out of your brother's eye."] (Mt 7: 4-5-5). Indeed, spiritual guides are necessary, but haven't they already taken God's place on earth when they replaced divine law with human traditions? Blind people who claim to lead others: Lăsați-i, ei sunt călăuze oarbe pentru orbi! Iar dacă un orb călăuzeşte un alt orb, amândoi cad în groapă" ["Leave them, they are blind guides for the blind! And if one blind man leads another blind man, they both fall into the pit"] (Mt 15:14) and their propaganda is nothing but a bad mound: ,IIn timp ce mulţimea se aduna cu miile, încât se călcau în picioare unii pe alţii, [Isus] a inceput să vorbească mai intâi discipolilor: „Feriţi-vă de aluatul fariseilor, care este ipocrizia, căci nu este nimic ascuns care nu va fi descoperit şi nici secret care nu va fi cunoscut! " ["While the multitude was in the thousands, so they trampled on one another, [Jesus] first began to speak to the disciples: "Beware of the leaven of the Pharisees, which is hypocrisy, for there is nothing hidden that will not be revealed and no secret that will not be known!'] ( $\mathrm{Lk} \mathrm{12,1-2).} \mathrm{This} \mathrm{is} \mathrm{the} \mathrm{state} \mathrm{of}$ the blind, the inability to recognize the signs of the times, that is, to reveal in Jesus of Nazareth the messenger of God. But the pride of the hypocrite has no limits and so he wants a sign from heaven: „Iar când bate vântul dinspre miazăzi, spuneţi că va fi cald şi aşa este. Ipocriţilor, aspectul pământului şi al cerului ştiţi să-l interpretaţi; dar de ce nu ştiţi să interpretaţi timpul de faţă?" ["And when the south wind blows, say that it will be warm and so it is. You hypocrites, you know how to interpret the appearance of the earth and the sky; but why do you not know how to interpret the present tense?"] (Lk 12: 55-56); blinded by his own wickedness, the hypocrite does not need the meekness and salvation brought by Jesus Christ and invokes the methodology, the law of the Sabbath, to keep him from doing good: „Atunci, Domnul $i$-a răspuns şi i-a zis: „Ipocriţilor! Nu-şi dezleagă fiecare dintre voi boul şi măgarul de la iesle şi-l duce la adăpat [chiar în zi de] sâmbătă? Şi această fiică a lui Abrahám, care era legată de Satana de optsprezece ani, nu trebuia să fie dezlegată în zi de sâmbătă?". ["Then the Lord answered and said to him," You hypocrites! Doesn't each of you untie his ox and the donkey from the manger and take it to the water [even on Saturday]? And this daughter of Abraham, who was bound to Satan for eighteen years, was not to be loosed on the Sabbath day?'] (Lk 13,15-16). The climax of the intrigue takes place the moment the hypocrite claims that Beelzebub is the instrument of Jesus' miracles, as if we were in the Harry Potter movie series: "But when the 
Bulletin of Integrative Psychiatry $\bigcirc$ New Series OSeptember 2021 Year XXVII ONo. 3(90)/127

\% \% \% \%

Pharisees heard it, they said, 'This fellow doth

not cast out devils, but by Beelzebub the chief of the devils'." (Mt 12,24). We are surprised, however, that they did not wonder if Jesus is a Freemason! But $\mathrm{He}$ is the prince of life, and in order to break down the gates of their hearts, Jesus will shame them before the community, exposing to them their hidden sin and decay: „Vai vouă, cărturarilor şi fariseilor ipocriţi! Voi zidiţi mormintele profeţilor şi impodobiţi monumentele drepților şi spuneţi: «Dacă eram în zilele părinţilor noştri, n-am fi fost complici cu ei la [vărsarea] sângelui profeţilor». Astfel, voi înşivă daţi mărturie împotriva voastră că sunteţi fiii celor ce au ucis profeții. Dar voi întreceţi măsura părinţilor voştri." ["Woe unto you, scribes and Pharisees, hypocrites! You build the tombs of the prophets and adorn the monuments of the righteous, and say, "If we were in the days of our fathers, we would not have been complicit with them in shedding the blood of the prophets." Thus testify against yourselves that you are the sons of those who killed the prophets. But you surpass your parents' measure."] (Mt 23,2932). And what is the end in the end? What we have to do? Here is the text: "But if that servant say in his heart, 'My lord delayeth his coming, he waits for the hour he does not know, he will punish him severely and make him one of the unbelievers." (Lk 12: 45-46). Let's wait full of zeal, wakefulness and confidence.

\section{THE AVAILABILITY AS A}

\section{PERMANENT RISK OF HYPOCRISY}

Let us not deceive ourselves and think that hypocrisy belonged only to the Pharisees of Jesus' day, and since then we have been immunized. No, the hypocrites have not disappeared. Of course, the synoptic tradition pushed the presumption of hypocrisy to all nations: „Apoi a spus mulţimilor:[...] Ipocriţilor [...]" ["Then he said to the multitudes, $[\ldots]$ to the hypocrites $[\ldots]$ ". $]$ ( $\mathrm{Lk}$ 12: 54-56). We understand the aspect, however maybe it was good for the Savior to make a statistic, a case study, a typology something; so St. John could no longer see through the Jews the unbelievers of all times. It is within everyone's reach to substantiate an ideology-philosophical-theological of opposites in society and to go with the sword through the world in the name of Jesus Christ. How? Has it already happened? Isn't the problem over? Who shouts, tolerance!? The Christian! It is said that either St. Peter did not escape this danger during the Antioch episode: „Dar, când a venit Chéfa la Antiohía, l-am înfruntat făţiş, căci era de condamnat. De fapt, inainte de a fi venit unii de la Iacób, stătea la masă cu păgânii, dar când au venit ei, s-a ferit şi a stat deoparte, temându-se de cei circumcişi. Împreună cu el au început să se poarte cu ipocrizie şi ceilalţi iudei, aşa încât şi Bárnaba a fost ademenit de ipocrizie. Dar când am văzut că ei nu merg drept, după adevărul evangheliei, i-am spus lui Chéfa în faţa tuturor: Dacă tu, care eşti 
128/Bulletin of Integrative Psychiatry ONew Series O September 2021 ○ Year XXVII ONo. 3(90)

r iudeu, te porţi ca un păgân şi nu trăieşti ca un addition we have extended ourselves with iudeu, cum îi poţi constrânge pe păgâni să trăiască asemenea iudeilor?" ["But when Chéfa came to Antioch, I openly confronted him, for he was to be condemned. In fact, before some came from Jacob, he sat at the table with the heathen, but when they came, he shunned and stood aside, fearing the circumcised. Along with him, the other Jews began to behave with hypocrisy, so that Barnabas was also seduced by hypocrisy. But when I saw that they did not walk uprightly, according to the truth of the gospel, I said to Chéfa in the presence of all: live like the Jews?"] (Gal 2: 11-15); but this is already another discussion and we prefer a little reserve. Let's go back to the clinical risks of our skidding. It didn't take long and the hypocritical scholars, from us and not only, needed a panacea, a word to avoid the Christian criteria of performance, namely the virtues. They found this miraculous word, availability, which emerged, to our knowledge, during the disaster of the French Revolution when, after shortening almost all the country's authority, they needed replacements. And it was difficult to tell your relative, your unqualified people, the proficient one, -so there the available relatives and totally unqualified for those positions gathered in all the key positions. And it was fine! We jump over times and history and see that nothing is new under the sun. We persevere and insist on mistakes and no one has the courage to cure themselves. In hypocrisy to the spiritual level of the perfect creation, let us turn dizzyingly to apostasy: „De altfel, Duhul spune clar că în timpurile de pe urmă unii îşi vor renega credinţa, luându-se după duhuri înşelătoare şi invăţături diabolice, [seduşi] de ipocrizia discursurilor false ale celor însemnaţi cu fierul roşu în cugetul lor" ["In fact, the Spirit clearly says that in later times some will renounce their faith, they are deceived by evil spirits and evil teachings, [seduced] by the hypocrisy of the false speeches of those marked with red iron in their minds"] (1 Tim 4: 1-2). Where is the meaning and why cannot we apply this quality, the availability of the human after all, to the religious, theological, spiritual discourse? Without determining pretentious linguistic analyzes, we find that specialists have emphasized in the semantics of the word in question, that trait specific to the individual as a state of mind in which feelings and reason are freely manifested and in their fullness. They, precisely the Christian teaching and the customs of the whole society in mind, have established that the religious and social individual needs the discernment of the facts and the moral-religious censorship. The word I referred to is successfully used for the human empirical, material, social plan. And the remedy comes, of course, also from Jesus Christ, through the rock of the foundation of his apostles, through St. Peter in addition to the problem, strengthened and persevering for good: "Therefore, removing 
Bulletin of Integrative Psychiatry $\bigcirc$ New Series OSeptember 2021 Year XXVII ONo. 3(90)/129

ry

all evil and all deception, hypocrisy, envy, and all evil speech, as newborn babies, desire spiritual milk, pure, that you may grow through it to salvation if you have indeed tasted how good the Lord is". (1 Pet. 1-4). So, no psychiatric control.

For more than a year we have been going through the sanitary pan-madness. We all remember that at the beginning of these problems, they had to align with the sanitary requirements and the church spaces. Indeed, the leaders of the religious edifices cheered in unison. The people will follow us through the internet, through television, the media is at the service of the individual. We witnessed uplifting, emotional, funny moments, some really comical, regardless of the confession we were referring to. Later, the same religious leaders began to moan, to tell us how sad it is to see shepherds without sheep. What to do? A restart of inter-social communication is required: "Humans are social beings and need to manifest themselves as such in the simplest ways that affirm their belonging to humanity: reason and communication. Even if most of the time the thought process is associated with the particular effort of silencing and distancing from the surrounding voices, in order to become reason, as Kant says, must be said and shared. Thinking becomes consistent only when it is brought into light and made known to others, discussed, challenged, questioned and understood, otherwise it is simply an empty exercise. The state of isolation and distancing between people has disrupted this normal movement of man throughout the world. The individual's need for humanity (to be a student, to be a child, a doctor, a researcher or anything else, to live in these times of crisis, to live, to care and educate those in need, to make discoveries, and to find the most appropriate solutions) can only be supported by effective communication, which goes beyond the barriers imposed by isolation and physical distancing. In a timely manner a responsible and informative communication is able to eliminate ambiguities while leading to understanding, knowledge and education" (8).

\section{CONCLUSIONS}

Hypocrisy belongs to the hypocrite, that is, to the individual in his ontic integrity as an immortal body, spirit, and soul. The individual lives in the community, so its first concern must be to rethink the work of sensitizing the people to the culture of life, not to the culture of waste and spoiled graves. We must also start from within the Christian communities, reversing the pyramidal structure, placing the people at the center of our concerns. With great clearness and courage to ask ourselves what type of culture we promote today in the family, in schools and universities, in research laboratories, in government forums. With clarity and determination let us discern the next steps in the service of life with all the fullness of its truth. One of these steps is, of course, to promote all environments of life in which justice and solidarity are expressed through every act and gesture of love and where the pathology has been cured. 
The authors declare that they have no potential conflicts of interest to disclose.

\section{REFERENCES}

1. Tamaș I, Tamaș C.Premisele bioeticii moderne în activitatea lui N. I. Camilli, primul episcop al Bisericii RomanoCatolice din Moldova (1884-1894; 1904-1915).Revista Română de Bioetică. 2011;9(1).

2. Tamaș I.. Mic dicționar teologic. Sapientia. 2008:263-265.

3. Toate citările biblice sunt făcute după: Biblia. Sapientia. 2013.

4. Vocabular de teologie biblică. Ed. Arhiepiscopiei Romano-Catolice de București. 2001:273-274.

5. Decret despre Ecumenism, „Unitatis Redintegratio”.Conciliul Ecumenic Vatican II.Traducerea Arhiepiscopiei Romano-Catolice de București. 1990:117.

6. Iosif Tamaș.Episcopul Marcu Glaser și dezlănţuirea urgiei comuniste. Vasiliana 98.2015:30.

7.Raportul Mccarrick, o pagină dureroasă din care Biserica are numai de învăţat.10.11.2020.Vatican. www.Catholica.ro.

8. Pricop L.. Reason and communication: digital form of communication in response to the COVID-19 pandemic. Bulletin of Integrative Psychiatry. 2020; 26: 3 (86).

\section{Correspondence}

\section{Iosif Tamas,}

$\mathrm{PhD}$, researcher, Institute of Interdisciplinary Research, Departament of Social Sciences and Humanities, Alexandru Ioan Cuza University of Iași, iosifta@yahoo.com

Submission: 10 jun 2021

Acceptance: 19 aug 2021 